\title{
유전자알고리즘을 이용한 막오염 시계열 예측 연구 \\ A Study on Time Series Analysis of Membrane Fouling by using Genetic Algorithm in the Field Plant
}

\author{
이진숙 ${ }^{\dagger} \cdot$ 김준현 · 전용성 · 곽영주 · 이진효* \\ Jin Sook Lee ${ }^{\dagger} \cdot$ Jun Hyun Kim • Yong Seong Jun • Young Ju Kwak · Jin Hyo Lee* \\ 인천광역시상수도사업본부 수질연구소 - *서울특별시보건환경연구원 대기환경연구부 \\ Water Quality Institute, Waterworks Headquarters, Incheon Metropolitan City \\ *Atmospheric Research Department, Seoul Metropolitan Government \\ Research Institute of Public Health and Environment
}

(Received April 21, 2016; Revised June 14, 2016; Accepted July 18, 2016)

\begin{abstract}
Most research on membrane fouling models in the past are based on theoretical equations in lab-scale experiments. But these studies are barely suitable for applying on the full-scale spot where there is a sequential process such as filtration, backwash and drain. This study was conducted in submerged membrane system which being on operation auto sequentially and treating wastewater from G-water purification plant in Incheon. TMP had been designated as a fouling indicator in constant flux conditions. Total volume of inflow and SS concentration are independent variables as major operation parameters and time-series analysis and prediction of TMP were conducted. And similarity between simulated values and measured values was assessed. Final prediction model by using genetic algorithm was fully adaptable because simulated values expressed pulse-shape periodicity and increasing trend according to time at the same time. As results of twice validation, correlation coefficients between simulated and measured data were $r^{2}=0.721, r^{2}=0.928$, respectively. Although this study was conducted limited to data for summer season, the more amount of data, better reliability for prediction model can be obtained. If simulator for short range forecast can be developed and applied, TMP prediction technique will be a great help to energy efficient operation.
\end{abstract}

Key Words : Membrane, Fouling Model, Genetic Algorithm, Time-series Analysis, Field Plant

요약 : 기존에는 lab-scale 연구에서 이론식을 기초로 막오염 모델식을 구성하였지만, 이러한 모델식은 여과, 역세, 배출이 연 속적으로 이루어지는 실규모 현장에 적용하기에는 적합하지 않았다. 본 연구는 실제로 인천시 G-정수사업소에서 발생되는 배출수 처리를 위해 연속자동 운전되고 있는 침지막 공정을 대상으로 진행되었다. 정유량 조건에서 막오염 관리지표를 막간 차압(Trans-Membrane Pressure, TMP)으로 결정하고 침지막 공정의 주요 운전변수인 총 투과유량과 조 내 SS농도를 독립변수 로 하여 TMP의 시계열 예측을 시도하고 예측 가능성 및 적용성을 평가하였다. 유전자알고리즘을 이용한 시계열 예측모형을 구성한 결과, TMP 예측값이 펄스주기 형태와 경시적인 증가 추세 두 가지를 모두 반영하고 있어서 만족할 만한 결과가 나왔 다. 두 번의 검증 결과, 선형회귀 방식으로 TMP 실측치와 예측치의 상관성(유의성)을 나타내면 각각 $\mathrm{r}^{2}=0.721, \mathrm{r}^{2}=0.928$ 수 준이다. 본 연구에서는 하절기 자료를 활용하여 모델링 작업을 수행하였지만 추후에 연속자료가 더 쌓이면 같은 절차로 모 델링 작업을 반복해서 더 높은 신뢰도의 예측모형을 구성할 수 있고 이를 실제 현장에 적용하여 2 3일 정도의 단기예측을 수행한다면 실제로 막공정을 에너지 효율적으로 운영하는데 도움이 될 것으로 사료된다.

주제어 : 멤브레인, 파울링 모델, 유전자알고리즘, 시계열 예측, 실증플랜트

\section{1. 서 론}

수처리 공정에서 막 표면에 케이크가 쌓인 상태로 오래 운전이 되면 비가역적인 막오염이 발생하여 막간차압(TransMembrane Pressure, TMP)이 증가하고 주기적인 세정 및 막 교체가 필요해 운영비가 많이 소요된다. ${ }^{1)}$ 막오염 현상 이 공정의 최적화 및 효율성을 결정하는 중요한 변수가 됨 에 따라 막오염 관리지표인 TMP에 대해 유체역학적 모델, 통계적 기법 및 두 형태가 결합된 방식을 적용하여 TMP를 예측하는 연구가 진행되고 있다. ${ }^{2,3)}$ 막오염에 대한 초기 모 델은 1935년 Hermans와 Bredee가 정압여과에 따른 세공막 힘(pore sealing), 중간세공협착(internal pore constriction), 입
자중첩에 의한 세공막힘(pore sealing with super-position) 및 케이크 여과(cake filtration) 형태의 모델을 제시하였지만 콜 로이드 또는 오염물질의 농도 및 운전시간과 같은 변수 적 용에 제약이 있었다. ${ }^{2,45}$ 이에 대한 개선으로 1882 년 Hermia 는 이 4종류의 막힘모델(blocking models)을 일반식으로 제 안하였으며, ${ }^{2,6)} \mathrm{Ho}$ 와 Zydney는 기존모델에서 입단증착(aggregate depositon)과 그 이후의 케이크 형성에 대한 개념을 확장시켰다. ${ }^{2,7)}$ Yuan 등은 수용액 상태의 휴믹산을 정밀여 과 시키는 과정에서 휴믹산 입단형성(aggregates)으로 인한 세공침착의 여과 오염에 대하여 기존 모델에서의 급격한 투 과유속 감소를 적용할 수 있도록 Ho와 Zydney식을 확장시 켰다. ${ }^{2,8)} \mathrm{Chllam}$ 과 $\mathrm{Xu}$ 는 콜로이드를 이용하여 정밀여과 중 
발생하는 오염현상에 적용할 수 있는 모델을 개발하였다. ${ }^{2,9)}$ 또한 Chellam과 Cogan은 Darcy 법칙을 근간으로 하여 기 존의 정압조건에서 유도된 적분식과 미분식을 정유량 운전 조건에서도 적용할 수 있는 통합모델을 제시하였다. ${ }^{2,10)}$ 국 내에서는 김대천과 정건용이 실험실적 규모의 평막형 $\mathrm{MBR}$ 시스템을 사용하여 투과유속에 따른 $\mathrm{TMP}$ 를 측정하고 여기 에 적분형 오염모델(blocking models)을 활용하여 오염모델 을 제시하였다. ${ }^{2}$ 하지만 대부분의 연구들이 실험실 규모로 이루어져 실규모 현장에 적용하는데 어려움이 있으며 막오 염은 여러 요인들이 복잡하게 결합되어 있어서 정확한 메커 니즘을 규명하기 어려운 실정이다. 이에 따라 최근에는 다양 한 알고리즘을 이용한 데이터마이닝 기법을 활용하여 fouling 속도를 예측하는 연구가 활발하게 진행되고 있다. Aidan 등 은 막공정에서 역세시점의 최적화를 위해 신경망 모델링을 활용하였으며 ${ }^{11)}$ Libotean 등은 RO 멤브레인 공정 운영에 신경망 알고리즘을 이용한 모델링을 수행하였다. ${ }^{12)}$ Moradi 등도 수학적 모델의 매개변수와 인공신경망 모델을 사용하 여 RO 멤브레인 공정의 모델화에 대해 연구하였다. ${ }^{13)}$ 국내 에서는 최용준과 황태문이 인공신경망 모델을 이용한 막오 염 지수 예측 연구를 수행하였고 ${ }^{14)}$ 정화원은 대표적인 선형 모델인 전이함수 ARIMA를 이용하여 막의 차압에 대한 모 델화에 대해 고찰하였다. ${ }^{15)}$

본 연구에서는 침지막 실규모 시설을 유입수의 부하 변동 등이 일어나는 실제 조건 하에서 연속자동 운전하여 얻은 운 전자료를 활용하였고 유전자알고리즘을 이용한 data processing을 통해 현장조건에 최적화된 막오염 지표인 TMP 시계열 예측모형을 개발하고 막오염 예측 기법을 평가하고자 하였다.

\section{2. 연구방법}

\section{1. 현장 실증플랜트}

본 연구가 수행된 장소는 인천시 $\mathrm{G}$-정수사업소로 풍납 취
수장을 취수원으로 하고 있다. 정수장 배출수 방류량은 약 $2000 \mathrm{~m}^{3} /$ day 이상으로 종전에 폐수 배출 1종사업장에 해당 되었으나 연구기간 중 방류수량 감소로 2015년 6월, 배출 2종사업장으로 변경되었다. 연구공정의 유입수는 침전지 슬 러지와 사여과지 역세척 배출수가 이송되는 배슬러지지의 상등수로서 농축조로 이송되기 전에 막여과 공정에서 처리 된 후 재이용되며 막여과 배출수는 원형 농축조로 이송된 다. 주요 실험 장치는 가로, 세로, 높이가 각각 $7.0 \mathrm{~m}, 2.0 \mathrm{~m}$, $5.0 \mathrm{~m}$ 인 사각 막분리조에 침지형 정밀여과막 카트리지 모듈 을 내부에 장착하여 배슬러지지 상등수를 Outside-in 방식 으로 연속 처리되도록 구성하였으며 공정 구성은 Fig. 1과 같다. 초기 연구공정 유입수 유량은 $760 \mathrm{~m}^{3} / \mathrm{d}$ 이며, 막면적은 제1막분리조의 경우 $864 \mathrm{~m}^{2}$ (단위 cartridge 막면적 $18 \mathrm{~m}^{2}$, frame당 12 개 cartridge 장착, 4 개 frame 침적) 제 2 막분리조 의 경우 $108 \mathrm{~m}^{2}$ (frame당 6개 cartridge 장착, 1 개 frame 침적) 이다. 침지막은 PVDF 재질의 침지형 중공사막을 사용하였 으며 전량여과(Dead-end flow)방식 및 정유량 조건으로 운 전하였다. 침지막 모듈에 대한 자세한 사항은 Table 1에 나 타내었다.

Table 1. Specification of membrane

\begin{tabular}{cc}
\hline Subject & Specifications \\
\hline \hline material & PVDF (permanently hydrophilic coating) \\
pore size $(\mathrm{um})$ & 0.1 and less \\
external/internal \\
diameter $(\mathrm{um})$ \\
membrane area $\left(\mathrm{m}^{2}\right)$ \\
flux range & $1100 / 600$ \\
TMP range & 18 \\
critical pressure & $0.2 \sim 1.0 \mathrm{~m}^{3} / \mathrm{m}^{2} \cdot \mathrm{d}$ \\
pH range & $-0.06 \mathrm{~kg}_{\mathrm{f}} / \mathrm{cm}^{2} \sim-0.6 \mathrm{~kg} / \mathrm{cm}^{2}$ \\
temperature range & $-0.7 \mathrm{~kg}_{\mathrm{f}} / \mathrm{cm}^{2}$ \\
& $1 \sim 10$ \\
\hline
\end{tabular}

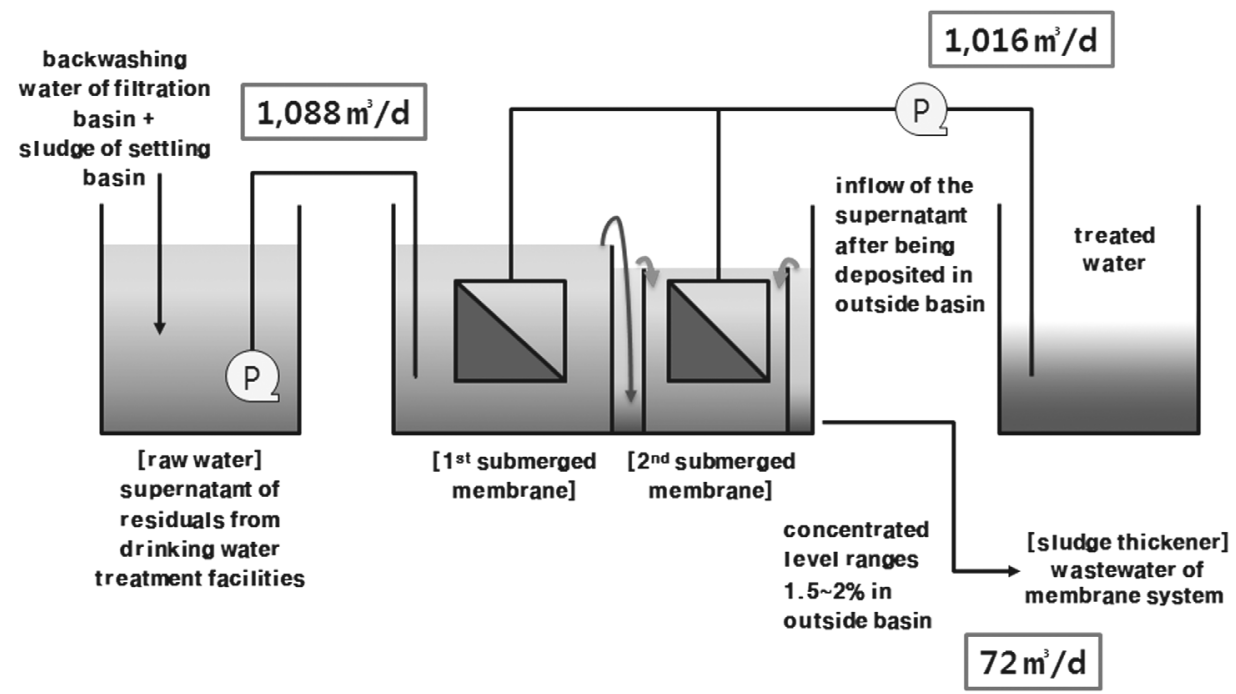

Fig. 1. Schematic diagram of the submerged membrane system (design value (recovery ratio: 93\%)). 


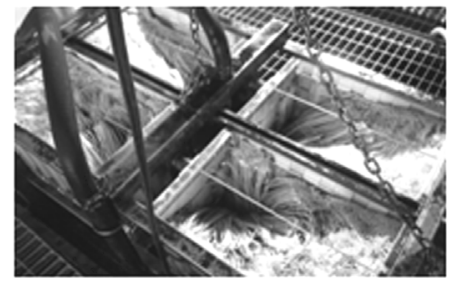

Fig. 2. Submerged membrane system.

Table 2. Operation mode of submerged membrane system

\begin{tabular}{cc}
\hline Mode & Operation \\
\hline \hline drain period & twice a day \\
CIP & $500 \mathrm{ppm} \mathrm{NaOCl}$, in the manner of backwash (2 min) \\
$\begin{array}{c}\text { (Cleaning- } \\
\text { in-place) }\end{array}$ a day & \\
air washing & $80 \mathrm{~m}^{3} / \mathrm{min}$ \\
\hline
\end{tabular}

\section{2. 플랜트 운전조건}

막오염 모델링을 위한 연속 운전자료를 얻기 위해 정유 량 조건에서 운전(여과)과 휴지(역세)를 반복하며 침지막을 운전하였고 투과유속 및 TMP 측정 등 모든 공정을 자동으 로 제어하였다. 침지막 여과공정에서 대상원수의 공급 형태 는 전량여과(Dead-end flow) 방식이고, 반응조 내에 막을 침 적시킨 후 $\mathrm{SS}$ 농도는 $58 \mathrm{mg} / \mathrm{L}$ 유입수 플럭스는 $0.6 \mathrm{~m} / \mathrm{d}$, 역 세척수 플럭스는 유입수 플럭스의 약 1.7 배인 $1.05 \mathrm{~m} / \mathrm{d}$, 세 정용 공기는 $80 \mathrm{~m}^{3} / \mathrm{min}$ 으로 초기 운전조건을 결정하고 침지 막 시스템을 운전하였다. 배출주기 및 세정방법은 pilot-plant scale의 선행 연구결과 ${ }^{11}$ 를 적용하여 Table 2 와 같으며, 9 분 여과, 1 분 휴지( 30 초 역세(처리수 + 폭기), 30 초 정지), 10 분 연속 폭기 방식이다.

\section{3. 유전자알고리즘 원리}

유전자 알고리즘(genetic algorithm, GA)은 생물진화(선택 도태, 돌연변이 등)의 원리로부터 착안된 알고리즘으로서 확률적 탐색이나 학습 및 최적화를 위한 기법 중 한가지이 다. 유전자 알고리즘은 문제의 잠재 해를 표현한 개체들로 이루어진 모집단을 가지고 시작한다. 모집단은 매 세대마

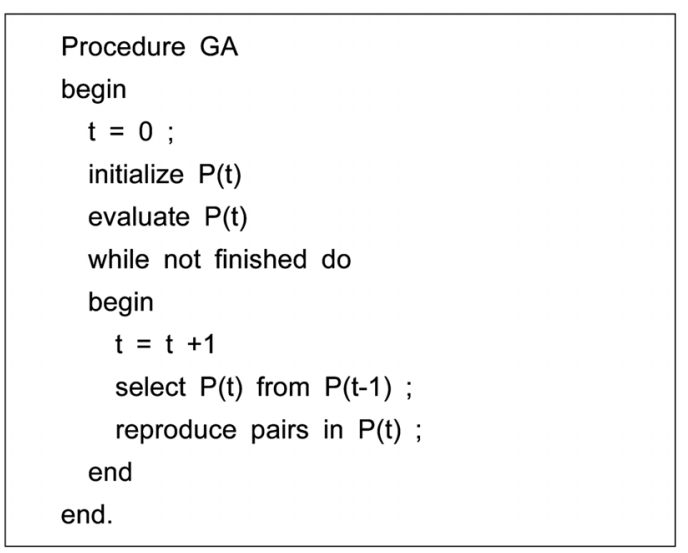

Fig. 4. A Simple Genetic Algorithm procedure GA.

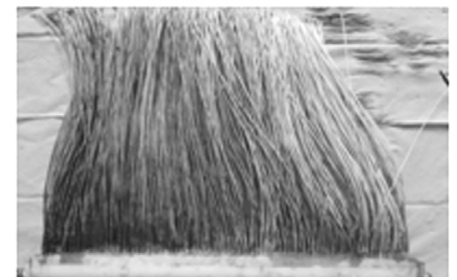

Fig. 3. Membrane surface.

다 일정수의 개체를 유지하고 매 세대에서 각 개체의 적응 도(fitness)를 평가하여 이에 따라 다음 세대에 생존한 개체 들을 확률적으로 선택(selection)한다. 선택된 개체들 중 일 부의 개체들이 임의로 짝을 지어 교배하여 자손을 생성한다. 이 때 교배(crossover)에 의해 부모의 유전자가 자손에서 상 속되고 이 과정에서 돌연변이가 일어난다. 자손은 부모로 부터 우수한 유전형질을 상속받는다고 가정함으로써 다음 세대의 잠재해들은 평균적으로 전 세대보다 더 발전된다고 본다. 이러한 진화과정은 종료조건이 만족될 때까지 반복 된다. 이 과정을 정리하면 Fig. 4와 같다. 여기서 $\mathrm{P}(\mathrm{t})$ 는 세대 t에서의 모집단을 나타낸다. ${ }^{12)}$

\section{4. 모델링 구성 및 적용}

모델식 $\mathrm{f}_{\mathrm{k}}$ 의 예측 정확도는 정규화된 평균제곱에러(normalized mean squared error, NMSE)를 예측함으로써 계산 가 능하다. 즉 시계열 예측 문제는 NMSE값을 최소화하는 예 측자(predictor) $\mathrm{f}_{\mathrm{k}}(X(\mathrm{t}))$ 를 찾는 문제로 귀결된다. 본 연구에 서는 시계열 자료에 대한 모델링으로 유전자 프로그래밍을 사용하였다.

독립변수에 해당되는 총 투과유량(parameter0)과 침지막 조 내 SS농도(parameter1) 자료값에 해당되는 이진수를 만 들고 유전자를 구성하였다. 생성한 유전자에서 재생산을 통 하여 우성인자들을 선택하였다. 주어진 변수에 해당되는 이 진수를 만들고 적합도함수를 구하여 적함도함수 값에 따라 다음 세대에 선택되어 지는데 2 개의 기본 연산자로서 교차 와 돌연변이가 있다. 돌연변이는 트리의 노드들의 값을 돌 연변이 확률에 따라 바낐고 교차는 두 부모 개체의 서브트 리를 교환하였다. 이 과정을 선택이라는 방법을 통해 미리 지정한 최대 세대까지 반복 수행하였다. 모든 선택 방법에 대해 엘리트 전략을 채용하여 최적의 개체는 항상 다음 세 대로 유지되도록 하였다. 적합도 함수는 모델링 예측치와 실측치의 차이값(절대값)으로 평가하였다. 모델링 작업에 사용된 함수 및 변수는 각각 Table 3,4 와 같다. 모델링 작 업에서 새로운 함수를 추가하고 불필요한 함수를 제거하는 과정이 반복해서 진행되었다. 또한 변수 선택도 경우의 수가 많기 때문에 기본값을 바꾸면서 모델링 작업을 반복하고 적 절한 값을 찾아가는 과정을 반복 수행하였다. 하절기(7월 16 일 8 월 15 일) 기간 동안 정유량 조건에서 침지막 시스템 을 운전하여 얻은 분당 연속자료를 활용하여 막오염 관리 지표인 TMP를 예측하는 막오염 시계열 예측 연구를 진행하 였다. 이 때 총 투과유량과 침지막조 내 SS농도는 독립변수 
에 해당되고, TMP는 종속변수에 해당된다. 자료구조는 트 리형태이고 수치해석은 공학용 수치해석 프로그램인 matlab (R2015a), 모델링 개발툴 프로그램은 python을 활용하였다.

Table 3. Definition of functions

\begin{tabular}{|c|c|}
\hline Functions & Definitions \\
\hline addw $(a, b)$ & $a+b$ \\
\hline subw $(a, b)$ & $a-b$ \\
\hline mulw $(a, b)$ & $a{ }^{*} b$ \\
\hline $\operatorname{divw}(a, b)$ & $\begin{array}{l}\text { if } b \text { is not zero }: a / b \\
\text { if } b \text { is zero }: a / 0.00001\end{array}$ \\
\hline $\operatorname{gtw}(a, b)$ & $\begin{array}{l}\text { if } a \text { is bigger than } b: 1 \\
\text { if } a \text { is not bigger than } b: 0\end{array}$ \\
\hline ifw $(a, b, c)$ & $\begin{array}{l}\text { if } \mathrm{a} \text { is bigger than zero }: \mathrm{b} \\
\text { if } \mathrm{a} \text { is not bigger than zero }: \mathrm{c}\end{array}$ \\
\hline $\log w(a)$ & $\begin{array}{l}\text { if a is bigger than zero : } \log (a) \\
\text { if } a \text { is not bigger than zero }: 0\end{array}$ \\
\hline absw (a) & abs (a) \\
\hline $\sin w(a)$ & $\sin (a)$ \\
\hline $\operatorname{smw}(a, b)$ & $\begin{array}{l}\text { if } a \text { is not bigger than } b: 1 \\
\text { if } a \text { is bigger than } b: 0\end{array}$ \\
\hline remw $(a, b)$ & $\begin{array}{l}\text { if } b \text { is not zero : } a \% b \\
\text { (the rest when } a \text { is divided into } b \text { ) } \\
\text { if } b \text { is zero }: a\end{array}$ \\
\hline $\operatorname{expw}(a, b)$ & $a^{b}$ \\
\hline
\end{tabular}

Table 4. Definition of variables

\begin{tabular}{cc}
\hline Variables & Values \\
\hline \hline maximum depth of tree data structure & 4 \\
mutation rate & 0.2 \\
fpr (probability of use tree node as functions) & 0.5 \\
1-ppr (probability of use tree node as constants) & 0.4 \\
ppr (probability of use tree node as parameters) & \\
- p0 : V (parameter0 means total volume) & 0.6 \\
- p1 : Cb (parameter1 means SS concentration) & \\
gene family size of the generation & 500 \\
\hline
\end{tabular}

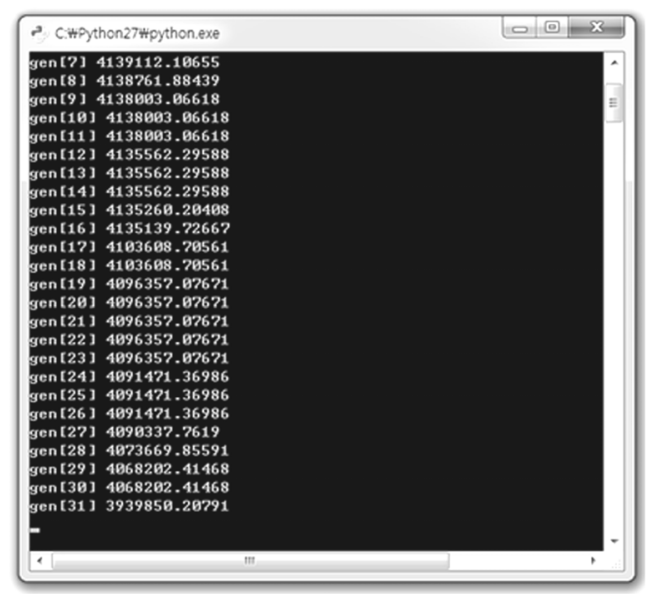

Fig. 5. Progress of genetic algorithm.

\section{3. 결과 및 고찰}

\section{1. 플랜트 운영결과}

하절기(2015년 7월 16일 8월 15일)기간 동안 실증플랜트 자동 연속운전 시 유입플럭스와 TMP 운영결과는 Fig. 6과 같다. 또한 같은 기간 동안 침지막조 내 $\mathrm{SS}$ 농도는 Fig. 7에 나타내었다. 유입플럭스, TMP, SS 농도는 분당 자료의 일 평균값을 나타내었다. 그리고 실제 유입원수의 변동에 따 라 화학세정 등 운전조건을 다르게 하여 세 개의 section으 로 구분하여 모델링을 수행하였다. 모델링은 분당 자료값 을 활용하였다. 첫 번째 section은 7월 16일부터 7월 21일까 지이며 유입플럭스가 $0.6 \mathrm{~m} / \mathrm{d}$ 에서 $0.5 \mathrm{~m} / \mathrm{d}$ 로 감소되는 부 분이다. 두 번째 section은 7월 21일부터 29일까지이며 유 입플럭스가 $0.5 \mathrm{~m} / \mathrm{d}$ 로 고정되어 운전되었던 부분이다. 첫 번째, 두 번째 section에서 각각 모델링을 작업을 수행해서 얻은 최종 모형구조식과 함께 자료구조 형태, 함수 종류, 변 수 값, 유전자 알고리즘 구동을 위한 설정 값 등을 활용하 여 세 번째 section에서 검증(validation)을 수행하였다. 세 번 째 section은 7월 30일부터 8월 9일까지이며 이 부분은 두 기간으로 나누어서 각각 검증을 수행하였다. section에 따른 운전조건은 Table 5에 나타내었다.

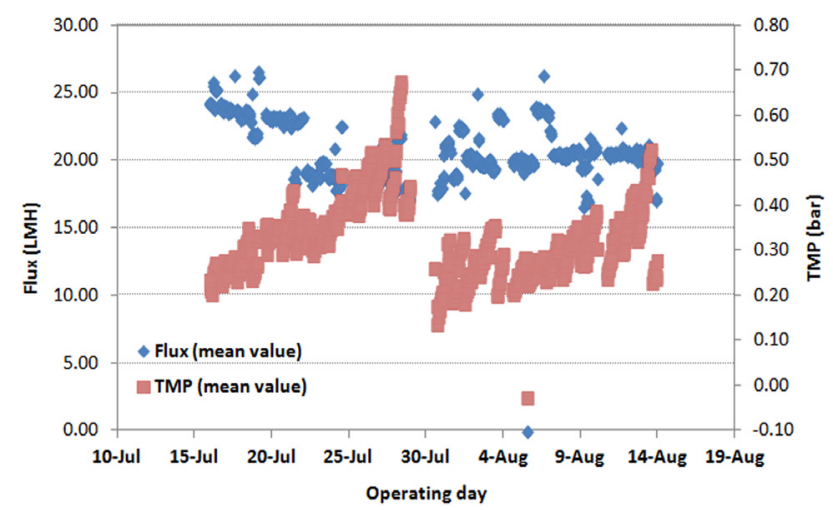

Fig. 6. Flux and TMP of the membrane system for the summer season.

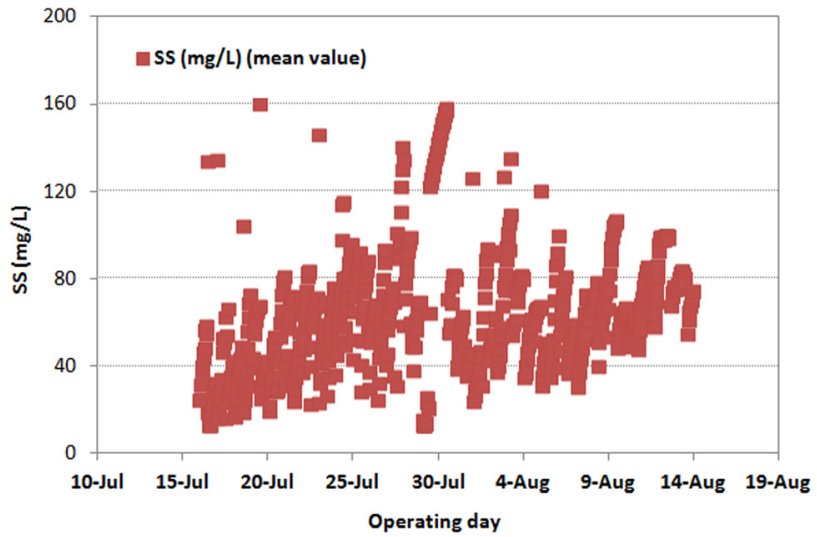

Fig. 7. SS concentration of the membrane system for the summer season 
Table 5. Operating conditions based on phases

\begin{tabular}{|c|c|c|c|}
\hline & 1st section & 2nd section & 3rd section \\
\hline flux (m/d) & $0.6,0.5$ & 0.5 & 0.5 \\
\hline CEB & 500 ppm & $\begin{array}{l}\text { (1) } 200 \mathrm{ppm} \\
\mathrm{NaOCl}\end{array}$ & $\begin{array}{l}\text { (1) } 200 \mathrm{ppm} \\
\mathrm{NaOCl}\end{array}$ \\
\hline $\begin{array}{c}\text { (Chemical Enhanced } \\
\text { Backwash) }\end{array}$ & $\mathrm{NaOCl}$ & 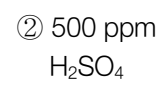 & $\begin{array}{c}\text { (2) } 500 \mathrm{ppm} \\
\mathrm{Na}_{2} \mathrm{~S}_{2} \mathrm{O}_{4}\end{array}$ \\
\hline $\begin{array}{l}\text { Inflow time of } \\
\text { activated carbon }\end{array}$ & \multicolumn{3}{|c|}{$6 / 28 \sim 7 / 18,8 / 7$} \\
\hline Note & \multicolumn{3}{|c|}{$\begin{array}{l}\text { additional cleaning : } 500 \text { ppm } \mathrm{Na}_{2} \mathrm{~S}_{2} \mathrm{O}_{4} \text { for ma- } \\
\text { nagement of manganese pollution, one a week }\end{array}$} \\
\hline
\end{tabular}

세 개의 section으로 구분한 이유는 현장 상황에 따라 유 입플럭스 및 화학세정 방법이 다르기 때문인데 이는 하절 기 기간 특성과 관련이 있다. 즉 고농도 조류가 발생할 경 우 수시로 활성탄이 유입되는데 활성탄은 투입이 중지되어 도 상당기간 배슬러지지 내에 잔류하여 막여과 공정에 영 향을 끼친다. 또한 배슬러지지는 활성탄 유입 및 수온 상승 에 따른 미생물 증가로 혐기성 상태가 될 수 있는 조건들이 발생함에 따라 배슬러지지 상등수 내 이온상태의 망간 비 율이 높아지게 되는데 침지막 공정으로 유입되면 산화환경 에서 입자성물질로 변화하여 막오염이 발생된다. 그러므로 최대한 막오염을 방지하고 계속 변화하는 현장조건에 대처 하면서 침지막 공정을 연속 운전하였다. 즉 고농도 원수 등 이 유입되는 등 심각한 막오염이 예상되면 section을 구분하 여 침지막 운영을 일시중지하고 모두 drain시킨 후 운전조건
을 바꾸고 막여과 공정을 운영하였다. 첫 번째 section 유지 세정은 유기세정만 진행하였고 $500 \mathrm{ppm} \mathrm{NaOCl}$ 을 역세할 때 역세방식으로 주입하였다. 두 번째 section 유지세정은 차 압관리를 위해 $500 \mathrm{ppm} \mathrm{H}_{2} \mathrm{SO}_{4}$ 의 산세정을 추가하였고 세 번 째 section 유지세정은 고농도 망간 유입이 관찰됨에 따라 $500 \mathrm{ppm} \mathrm{Na} \mathrm{S}_{2} \mathrm{O}_{4}$ 의 침지식 세정을 추가하였다.

\subsection{1 st section 모델링 결과}

첫 번째 section 자료를 이용하여 모델링 작업을 수행한 결과는 Fig. 8에 나타내었다. x축은 총 투과유량(total volume) 이고 정유량 조건으로 운전되므로 운전시간과 동일한 의미 를 가진다. 학습 data 개수는 1440 개(random), 예측 data 개 수는 6359 개, 사용된 함수는 addw, subw, mulw, divw, ifw, $\log w, \mathrm{gtw}, \mathrm{absw}, \mathrm{sinw}, \mathrm{smw}$, expw, 오차 합은 269.3468 이다.

\subsection{2nd section 모델링 결과}

두 번째 section 자료를 이용하여 모델링 작업을 수행한 결 과는 Fig. 9에 나타내었다. 학습 data 개수는 1156개(random), 예측 data 개수는 11699 개, 사용된 함수는 addw, subw, mulw, divw, ifw, logw, gtw, absw, sinw, smw, expw, 오차 합은 465.5570 이다.

\subsection{3rd section 모델링 결과(validation)}

첫 번째, 두 번째 section에서 모델링 작업을 각각 수행하

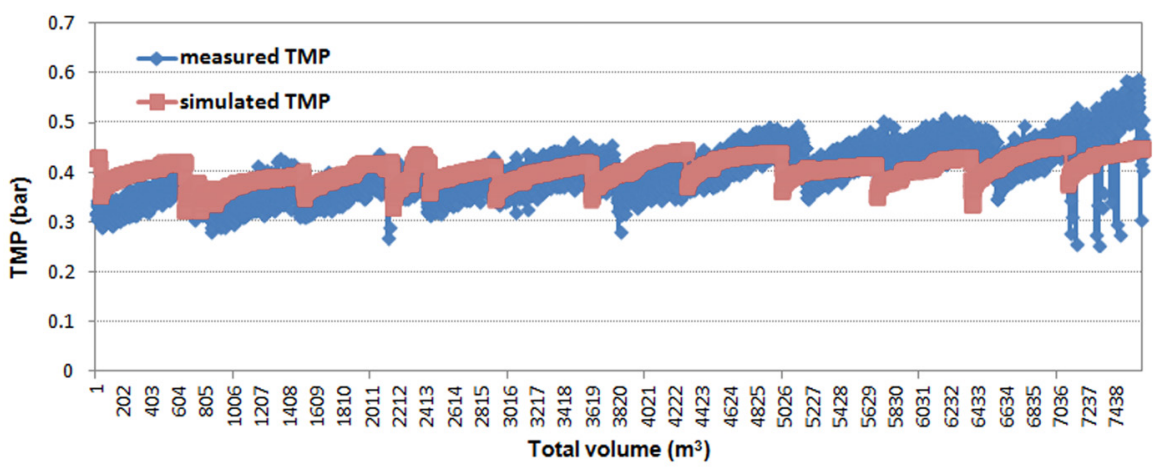

Fig. 8. Comparison between simulated and observed values of 1st section.

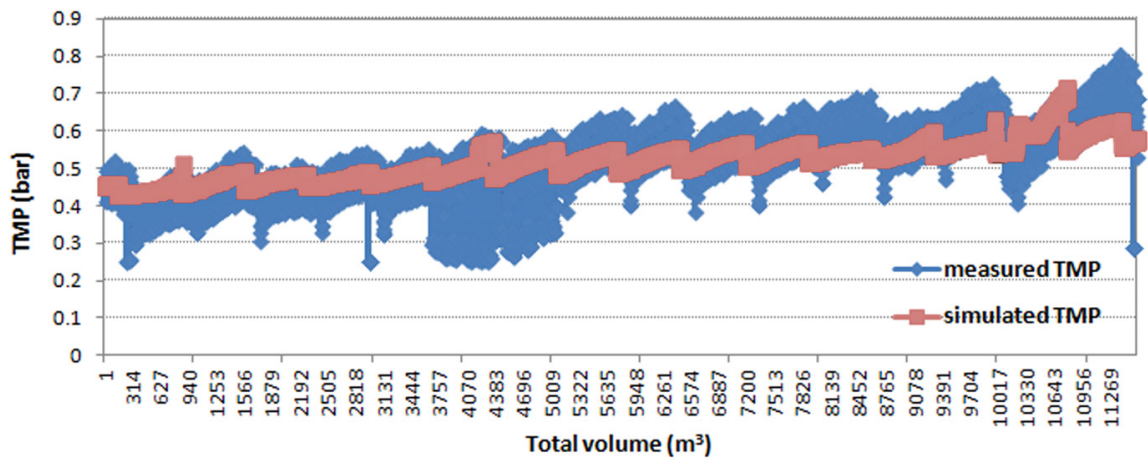

Fig. 9. Comparison between simulated and observed values of 2nd section. 
고 이를 통합하여 최종 예측모형을 구성하였다. 모델링 작 업을 수행에서 얻은 자료구조 형태, 함수 종류, 변수 값, 유 전자 알고리즘 구동을 위한 설정 값 등 최적 modeling setting 과 예측모형 구조식을 활용하여 simulation을 수행하고 세 번째 section 실측자료와 비교, 검증을 수행한 결과는 Fig. 10,11 에 나타내었다. 세 번째 section은 데이터 개수가 많은 관계로 (a)부분과 (b)부분으로 나누어서 각각 비교하였으며, 초기 차압값 $\left(\mathrm{P}_{0}\right)$ 을 입력 값으로 사용하고 함수는 동일하게 addw, subw, mulw, divw, ifw, logw, gtw, absw, sinw, smw, expw를 사용해서 검증하였다. 오차 합은 각각 (a) 238.6469, (b) 286.9695이다. Fig. 12에서는 선형회귀 방식으로 TMP 실측치와 예측치의 상관성(유의성)을 나타내었다. (a)는 침 지막 drain 직후 운전이 시작되는 부분이 포함되어 있어서 실측치와 예측치의 차이가 다소 크게 나타났지만 시간이 지 나고 공정이 안정화되면서 (b)에서는 실측치와 예측치의 유 의성이 개선됨을 $\mathrm{r}^{2}$ 값을 통해 확인할 수 있다. Fig. 13에서

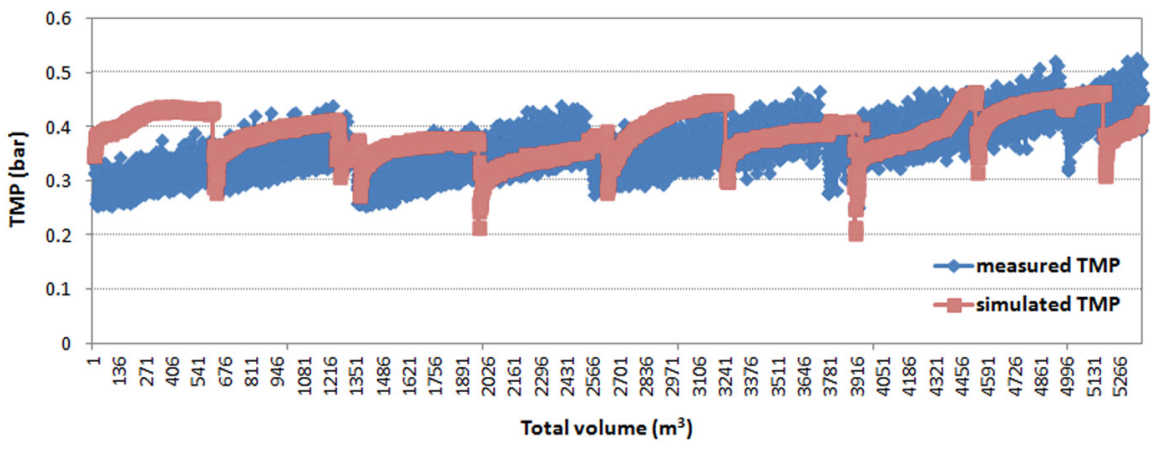

Fig. 10. Comparison between simulated and measured values of 3rd section-(a).

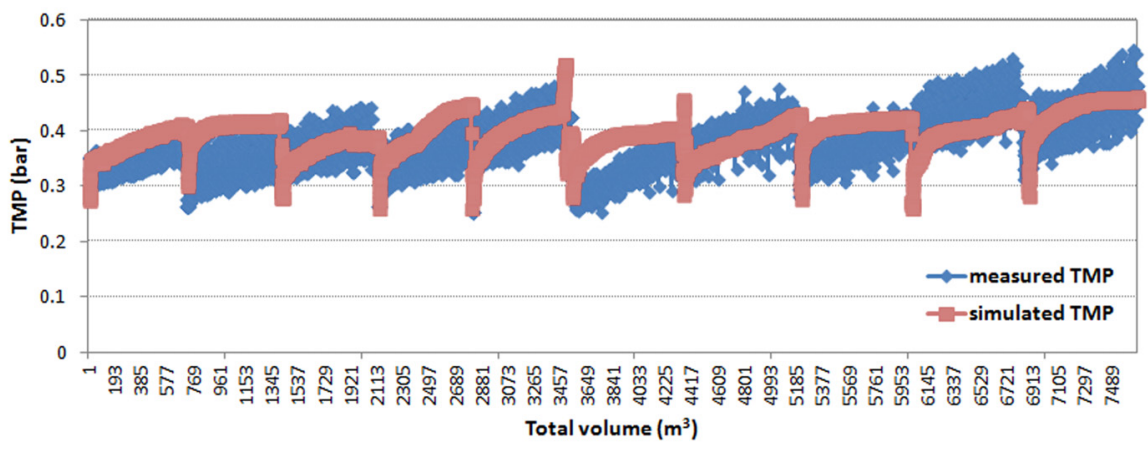

Fig. 11. Comparison between simulated and measured values of 3rd section-(b).
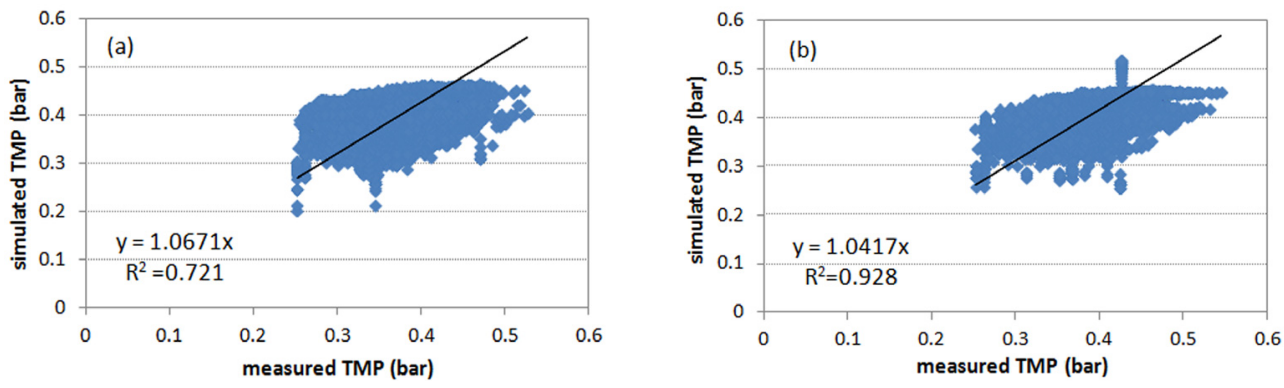

Fig. 12. Correlation evaluation between simulated and measured data.
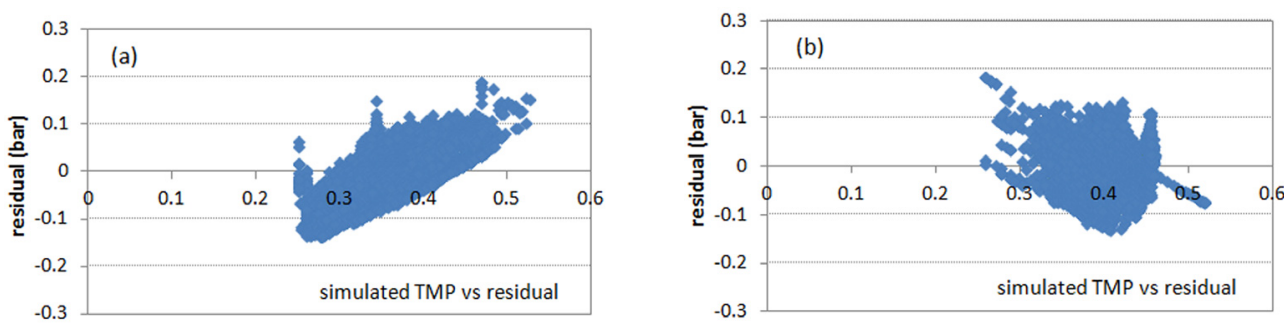

Fig. 13. Residual diagram of simulated TMP ((a) $\mathrm{N}=5379$, (b) $\mathrm{N}=7676$ ). 
는 시계열 예측 모형을 통해 예측된 $\mathrm{TMP}$ 값과 회귀식으로 계산된 TMP값의 차이값을 나타내었다.

\section{4. 결 론}

본 연구는 lab scale 실험에서 파울링 이론식을 기초하여 막오염 모델식을 구성했던 기존 연구와는 달리 자동 연속운 전이 이루어지는 현장 실증플랜트의 운전자료가 활용되었 고 유전자알고리즘을 이용한 막오염 시계열 예측 기법을 개 발하여 현장조건에 맞는 막오염 예측 가능성을 검토하고자 추진되었으며 다음과 같은 결론을 도출하였다.

1) 실규모 시설을 유입수의 부하 변동 등이 나타나는 실 제 조건 하에서 자동 연속운전하여 얻은 운전자료를 활용 하여 모델링에 적용한 결과이기에 현장에 적용 가능한 막오 염 예측 연구로서 중요한 의미가 있다고 사료된다.

2) TMP 값의 높이, 넓이에 대한 규칙성이 모호하고 실증 플랜트의 연속운전 자료이므로 튀는 값이 많아서 모델링 작업의 어려움이 있었으나, 주기성(pulse 형태)이 있고 시간 에 따라 전체적인 증가 추세 경향이 있기 때문에 이 두 가 지를 동시에 구현하기 위한 시계열 예측 모델링을 시도하 였다. 검증결과를 보면 TMP 예측치의 주기성과 경시적인 증가 추세 두 가지를 모두 반영하고 있어서 만족할만한 결 과가 나왔다.

3) 세 번째 section에서 선형회귀 방식으로 TMP 실측치와 예측치의 상관성(유의성)을 나타내면 (a) $r^{2}=0.721$, (b) $r^{2}=$ 0.928 수준이다.

4) 막오염 예측 연구는 추후에 연속자료가 더 쌓이면 같 은 절차로 모델링 작업을 반복해서 더 좋은 신뢰도의 모델 식을 구성하고 이를 적용해서 2 3일 정도의 단기예측을 수 행하는 것이 실제로 막 시스템을 효율적으로 운영하는데 도 움이 될 것으로 판단된다. 이번 연구를 통해 안정적으로 운 영되는 막공정 현장에 적용 가능한 TMP 단기예측 시뮬레 이터 개발도 기대할 수 있을 것으로 사료된다.

5) 막오염 속도를 예측하는 연구를 통해 이루려는 막 시 스템 공정의 최적화는 장기적으로 보면 막 성능을 최대한 활용하면서 불필요한 세정을 줄이고 막 수명 연장 및 에너 지 절약으로 이어지므로 fouling 속도를 예측하는 모델식을 개발하여 침지막 운전을 smart하게 제어하는 것은 중요하 다고 사료된다.

6) 본 연구는 하절기 자료를 활용하여 TMP 단기예측 모 델링을 수행하였지만 향후 실증플랜트를 장기 운영하면서 계절에 따른 특성 및 TMP jumping 현상을 관찰하면 원수 수온 등 막오염에 영향을 미치는 주요 변수들을 모델링 작 업에 추가하고 이에 따라 연중 막여과 공정을 운영할 때 갑작스런 TMP jumping 현상을 예측할 수 있는 모델식 개발 이 가능할 것으로 사료된다.

\section{Acknowledgement}

본 연구는 환경부의 재원으로 에코스마트상수도시스템 개 발사업(GT-SWS-11-01-003-0)의 지원을 받아 수행되었으며 이에 감사드립니다.

KSEE

\section{References}

1. Kim, B. G., "Prediction of membrane fouling by using flux decline model in microfiltration," University of Seoul(2011).

2. Kim, D. C., "Membrane fouling models for activated sludge cakes," Membr. J., 24(3), 249 257(2014).

3. Kaneko, H. and Funatsu, K., "Physical and statistical model for predicting a transmembrane pressure jump for a membrane bioreactor," Chemometr. Intell. Lab., 121, 66 74(2013).

4. Hermans, P. H. and Bredee, H. L., "Principles of the mathematical treatment of constant pressure filtration," J. Soc. Chem. Ind., 55, 1(1936).

5. Michael, J. M. and Orr, C., "Filtration: principles and practices,” Marcel Dekker Inc., New York, pp. 135 139(1987).

6. Hermia, J., "Constant pressure blocking filtration laws-application to power-law non-newtonian fluids," Trans. Inst. Chem. Eng., 60, 183(1982).

7. Ho, C. C. and Zydney, A. L., "Transmembrane pressure profiles during constant flux : microfiltration of bovine serum albumin," J. Membr. Sci., 209(2), 363 377(2002).

8. Yuan, W., Kocic, A. and Zydney, A. L., "Analysis of humic acid fouling during microfiltration using a pore blockagecake filtration model," J. Membr. Sci., 198(1), 51 62(2002).

9. Chllam, S. and Xu, W., "Blocking laws analysis of dead-end constant flux microfiltration of compressible cakes," J. Colloid. Interf. Sci., 301(1), 248 257(2006).

10. Chellam, S. and Cogan, N. G., "Colloidal and bacterial fouling during constant flux microfiltration: comparison of classical blocking laws with a unified model combining pore blocking and EPS secretion," J. Membr. Sci., 382(1), 148 157 (2011).

11. Aidan, A., Abdel-Jabbar, N., Ibrahim, T. H., Nenov, V. and Mjalli, F., "Neural network modeling and optimization of scheduling backwash for membrane bioreactor," Clean Technol. Environ. Policy, 10(4), 389 395(2007).

12. Libotean, D., Giralt, J., Rallo, R., Wolfe, T. and Cohen, Y., "Neural network approach for modeling the performance of reverse osmosis membrane desalting," J. Membr. Sci., 326 (6), 408 419(2009).

13. Moradi, A., Mojarradi, V. and Sarcheshmehpour, M., "Prediction of RO membrane performances by use of artificial neural network and using the parameters of a complex mathematical model," Res. Chem. Intermediates, 39(7), 3235 3249(2012).

14. Hwang, T. M., Choi, Y., Nam, S. H., Lee, S., Oh, H., Hyun, K. and Chong, Y. K., "Prediction of membrane fouling rate 
by neural network modeling," Desalination and Water, 15 (1/3), 134 140(2010).

15. Jung, H. W., "A Study on the Improvement of Recovery Rate, Modeling and Economical Control in the UF/RO Process for Wastewater Reuse," University of Seoul(2013).

16. Kim, J., H., "A study about treatment for water treatment residual sludge using submerged membrane system," J. Korean Soc. Water and Wastewater, 28(2), 181 193(2014).

17. Ha, S. J., "Presupposing the water qaulity of Youngsan River by combined Method of Genetic Algorithm and Neural Network," Dongshin University(2003).
18. Parneet, P., "Development and testing of a fully adaptable membrane bioreactor fouling model for a sidestream confiquration system," Membranes, 3(2), 24 43(2013).

19. Gianpaolo, S. M. F. and Alessandro, S., "Online monitoring of MBR fouling by transmembrane pressure and permeability over a long-term experiment," Sep. Purific. Technol., 122, 297 305(2014).

20. Otok, B. W. and Suhartono, "Development of rainfall forecasting model in Indonesia by using ASTAR, transfer function, and ARIMA methods," Eur. J. Sci. Res., 38(3), 386 395 (2009). 